\title{
TO STUDY THE DURATION OF ONSET OF SYMPTOMS, DIAGNOSIS AND CAUSES OF DELAY IN TREATMENT-INITIATION OF TUBERCULOSIS PATIENTS REGISTERED UNDER RNTCP IN KARAD TU
}

\author{
Vandana Bhoi ${ }^{1}$, Anil Bhoi
}

${ }_{1}^{1}$ Associate Professor, Department of Community Medicine, PIMSR, Islampur, Maharashtra.

${ }^{2}$ Associate Professor, Department of Paediatrics, PIMSR, Islampur, Maharashtra.

\begin{abstract}
BACKGROUND
ABSTRACT

Tuberculosis is a chronic communicable bacterial disease. The chance of developing the disease is maximum shortly after infection. An active case of pulmonary tuberculosis is the most important component in disease spread within the community. The diagnosis of all forms of tuberculosis depends on identification or isolation of the causative organism. So, it is important to know the duration of onset of symptoms, diagnosis and causes of delay in treatment-initiation of tuberculosis patients registered under the Revised National Tuberculosis Programme (RNTCP).

Aims and Objectives- To study the duration of onset of symptoms and diagnosis of patients and causes of delay in treatmentinitiation of tuberculosis (TB) patients registered under RNTCP in Karad Tuberculosis Unit (TU).
\end{abstract}

\section{MATERIALS AND METHODS}

The present longitudinal (Prospective) study was carried out during January 2008 to June 2009 on patients registered at Karad TU catering 9 PHCs, Sub-District Hospital, Krishna Hospital and 6 DMCs with 3 ICTCs. In total, 806 patients were study subjects with prior permission of District Tuberculosis Officer (DTO). Patients were interviewed using semi-structured questionnaires at their residence in defined time period, i.e. at the start of treatment after completion of IP.

\section{RESULTS}

In the present study in $314(39 \%)$ of patient's period between onset of symptoms and diagnosis was 2 weeks, while it was more than 2 weeks in $492(61 \%)$ patients. There was delay in treatment-initiation in $297(60.4 \%)$ patients, because they went to private practitioners for treatment.

\section{CONCLUSION}

The study results revealed that 294 (36.5\%) patient's period between onset of symptoms and diagnosis was 2 weeks, while it was more than 2 weeks in 492 (61\%). It was found that the cause of delay in treatment-initiation in 297 (60.4\%) patients was because they went to private practitioners for treatment.

\section{KEYWORDS}

RNTCP, TU, TB.

HOW TO CITE THIS ARTICLE: Bhoi V, Bhoi A. To study the duration of onset of symptoms, diagnosis and causes of delay in treatment-initiation of tuberculosis patients registered under RNTCP in Karad TU. J. Evolution Med. Dent. Sci. 2018;7(18):22852287, DOI: $10.14260 /$ jemds/2018/513

\section{BACKGROUND}

Tuberculosis is one of the man's oldest foes. India is one of the worst affected countries among the most feared. One of the triumphs of modern medicine has been the development of vaccination and medication capable of combating this ancient disease. Yet tuberculosis remains our major concern.

It is a very peculiar disease because of its varied clinical presentation, host response, chemotherapeutic response, aetiology and social implications. Its description has also been found in Buddhist and Chinese writings. ${ }^{1}$ This is a bacterial disease caused by Mycobacterium Tuberculosis. They are sometimes referred to Acid Fast Bacilli (AFB).

'Financial or Other Competing Interest': None.

Submission 21-03-2018, Peer Review 13-04-2018,

Acceptance 20-04-2018, Published 30-04-2018.

Corresponding Author:

Anil Bhoi,

Ganeshnagar, Near St Stand,

Islampur Tal-Walwa,

Dist-Sangli,

Maharashtra

E-mail: dranilbhoi@yahoo.com

DOI: $10.14260 /$ jemds $/ 2018 / 513$
The disease spreads when an infected person coughs or sneezes and someone else inhales the droplets. Bacillus in the sputum remains alive for 20 - 30 hours and in droplet nuclei for 8 - 10 days. Tuberculosis develops in people in whom immune system does not successfully deal with the primary infection. If left untreated, each person with active TB will infect on an average between 10 - 15 people every year. In India is in adults aged 15 - 45 years, which include the most productive members of society, thereby causing huge economic disruption which in turn hampers the development of the country.

Men have to deal with the stigma at their workplace and in the community and women are ostracised in household and community. ${ }^{1}$

The stigma attached to TB adds to burden of disease for both men and women, even more so if they are marriageable age. Studies indicate that 1 lakh women are rejected by their families each year on account of tuberculosis. ${ }^{2}$

For more than two decades, tuberculosis has been recognised as major opportunistic infection in patients with HIV and AIDS infection.

Phase-II of the RNTCP is a step towards achieving the TB related Millennium Development Goals (MDG) targets. It aims to further improve the access of services to marginalised 
groups, in hard to reach areas with intensive monitoring, supervision and evaluation. To provide good standardised good quality service in a patient friendly environment, the programme will strengthen the intersectoral collaboration, involve medical colleges and conduct need based and peoplecentric information, education and communication (IEC) activities. Government had recognised that medical colleges, private practitioners and NGO's play an active role in health promotion of community and for the case finding to improve the sectors also need to be involved.

\section{Aims and Objectives}

1. To study the duration of onset of symptoms and diagnosis of patients registered under RNTCP in Karad Tuberculosis Unit.

2. To study of causes of delay in treatment-initiation of tuberculosis patients registered under RNTCP.

\section{MATERIALS AND METHODS}

\section{Study Cohort}

All patients were registered in Karad Tuberculosis Unit selected from January 2008 to June 2009. 806 patients formed the study cohort. Hence, no sampling procedure was used. Under Karad Tuberculosis Unit there are 9 PHCs, SubDistrict Hospital and Krishna Hospital, 6 Designated Microscopy Centres (DMC), 3 Integrated Counselling and Testing Centres (ICTC). Before commencement of study, permission of District Tuberculosis Officer (DTO) was taken.

\section{Study Period}

January 2008 to June 2009. Data collection from October 2008 to April 2010 and analysis was done in May 2010 using appropriate techniques.

\section{Type of Study}

Longitudinal (Prospective) Study.

\section{Study Plan}

Data Collection: Patients were interviewed using pre-tested semi-structured questionnaires at their residence after treatment-initiation, after completion of intensive phase (IP) and at the end of continuation phase.

\section{Statistical Methods}

(Data Analysis) Data was summarised in number and in percentage. Appropriate techniques used. Chi-square test was applied to assess statistical significance between variables.

\section{RESULTS}

\begin{tabular}{|c|c|c|c|}
\hline \multirow{2}{*}{ Duration } & \multicolumn{2}{|c|}{ Gender } & \multirow{2}{*}{ Total } \\
\hline & Male & Female & \\
\hline 1 Week & $11(2.3 \%)$ & $9(2.9 \%)$ & $20(2.5 \%)$ \\
\hline 2 Weeks & $188(39.6 \%)$ & $106(32 \%)$ & $294(36.5 \%)$ \\
\hline $\begin{array}{c}3 \text { Weeks and } \\
\text { more }\end{array}$ & $276(58.1 \%)$ & $216(65.3 \%)$ & $492(61 \%)$ \\
\hline Total & $475(100 \%)$ & $331(100 \%)$ & $806(100 \%)$ \\
\hline \multicolumn{4}{|c|}{$\begin{array}{l}\text { Table 1. Distribution of Patients according to Duration } \\
\text { between Onset of Symptoms and Diagnosis }\end{array}$} \\
\hline
\end{tabular}

$\chi 2=4.814, \mathrm{df}=2, \mathrm{p}=0.090$.

\begin{tabular}{|c|c|c|}
\hline Causes & Frequency & Percent (\%) \\
\hline $\begin{array}{l}\text { Under private practitioner's } \\
\text { treatment }\end{array}$ & 297 & 60.4 \\
\hline Due to daily wages loss & 89 & 18 \\
\hline Negligence & 87 & 17.7 \\
\hline Lack of awareness & 19 & 3.9 \\
\hline Total & 492 & 100 \\
\hline
\end{tabular}

\section{DISCUSSION}

We observed distribution of patients according to duration between onset of symptoms and diagnosis. In the present study in 314 (39\%) of patients period between onset of symptoms and diagnosis was 2 weeks, while it was more than 2 weeks in $492(61 \%)$ patients. There was no significant association between onset of symptoms and gender of patients in this study. In tuberculosis patients, usually primary action against symptom takes the form of home remedy and self-medication, as a delay in reporting by patients to health services can increase the risk of transmission of disease to the community and family. This is clearly a serious threat to primary objects of NTP to reduce TB prevalence. Obviously, the aim of treatment is to avoid harm to the individual patient and to have as many years of healthy life as possible or prolong the life of TB patients. Therefore, emphasis needs to be placed to contact tracing which may have high yield of new cases. Delay also bears the risk of introducing infection to unexposed or more vulnerable group of population. Therefore, emphasis needs to be placed to contact training, which may have high yield of new cases.

The following studies share the findings. Rajeshwari R et $\mathrm{al}^{3}$ has found that median patient delay was 20 days (range 0 240 ), $29 \%$ of patients have waited for one month or longer to seek care with mean health system delay of 23 days and total mean delay of 60 days ( $0-425)$. Out of these 531 patients in $33(6.21 \%)$ reason for delay was age above 45 years, in 35 $(6.59 \%)$ reason was illiteracy, in $31(5.83 \%)$ reason was unemployment, in 34 (6.4\%) reason for delay was low family income, in $34(6.4 \%)$ reason for delay was distance $>2 \mathrm{~km}$ from a health facility, in $36(6.77 \%)$ reason for delay was alcoholism, while in $37(5.83 \%)$ reason for delay was residence in rural area.

Yamasaki-Nakagawa $\mathrm{M}$ et $\mathrm{al}^{4}$ have found that median total delay is 2.3 months for men and 3.3 months for women, while the median health care providers delay was 1.5 months for males and 3 months for women. They also found that median total delay was 2.3 months for men and 3.3 months for women, while the median health care providers delay was 1.5 months for men and 3 months for women. In 42 (12.5\%) reasons for delay was visit to traditional healers, in 165 $(49.10 \%)$ reason for delay was visit to private healthcare provider, in $79(23.5 \%)$ reason for delay was Government Medical establishment, in $45(13.40 \%)$ reason for delay were others, while in $5(1.40 \%)$ reasons were unknown.

Paynter $\mathrm{S}$ et al ${ }^{5}$ have found that median patient delay was 34.5 days, while median health care delay was 29.5 days. They also found that out of 71 patients in 37 (52.11\%) reason for the delay was the first contact with GP, in 9 (12.6\%) patients visited health care system only accidentally or in emergency, while in 37 (43.6\%) reason for delay was absence of classic TB symptoms. 
Gopi PG et $\mathrm{al}^{6}$ in a study found that among 243 smear positive patients, 57 patients were not registered for treatment, $24.4 \%$ males and $17.6 \%$ females were initial defaulters due to unwillingness for initiation of treatment, symptoms too mild, too sick and old, and work-related problems.

It was found in this study that causes of delay in treatment-initiation in $297(60.4 \%)$ was they went to private practitioners for treatment, in 19 (3.9\%) patients delayed due to lack of awareness, in $87(17.7 \%)$ patients delay was because of negligence, in $89(18 \%)$ reason for delay was loss of daily wages. The most common cause of delay in initiation of treatment was among patients being treated by private practitioners.

In present study, we have found that common causes for delay in treatment-initiation of DOTS is that patient did not avail the care of government health facility due to their job. It is therefore necessary to educate private health care providers for screening of cases and also to develop a good referral system.

To cope up with problems like negligence, lack of awareness, alcoholism, information, education and communication activities should be intensified. The present study findings are consistent with the following studies.

Rajeshwari R et al,3 Yamasaki-Nakagawa $\mathrm{M}$ et al,4 Paynter $S$ et al $^{5}$ and Gopi PG et al, 6 in whom the common finding have been private practitioner's delay and negligence. They have also found reasons like old age, unemployment, visit to health care system accidentally or in emergency. The failure of private practitioner to diagnose tuberculosis and continued symptomatic therapy for long period of time.

\section{CONCLUSION}

The study results revealed that $294(36.5 \%)$ patient's period between onset of symptoms and diagnosis i.e. 2 weeks, while it was more than 2 weeks in 492 (61.\%). It was found that causes of delay in treatment-initiation in 297 (60.4\%) was they went to private practitioners for treatment, in $19(3.9 \%)$ patients they delayed due to lack of awareness, in $87(17.7 \%)$ patients the delay was because of negligence and in $89(18 \%)$ reason for delay was loss of daily wages. The most common cause of delay in initiation of treatment was among patients being treated by private practitioners.

\section{Recommendations}

1. We need to motivate and convince patients the need for DOTS and the need for initiation of treatment immediately and to complete treatment by health education on mass basis.

2. Private practitioners, Paediatricians and Physicians should make it compulsory for the registration of their TB patients under RNTCP.

3. GPs should be given regular RNTCP orientation training and they should be informed to send or refer each suspected case to nearest DMC for sputum examination.

4. Health education must be imparted to patient on mass basis by health worker at initiation of treatment as well as intermittently during therapy.

\section{REFERENCES}

[1] Kishore J. National health programmes of India. $7^{\text {th }}$ edn. New Delhi, Century Publications, 2007:168-70.

[2] TB India, RNTCP annual status Report, 2005:8-9. https://tbcindia.gov.in/showfile.php?lid=2917ion.

[3] Rajeswari R, Chandrasekaran V, Suhadev M, et al. Factors associated with patients and health system delays in the diagnosis of tuberculosis in South India. Int J Tuberc Lung Dis 2002;6(9):789-95.

[4] Yamasaki-Nakagawa M, Ozasa K, Yamada N, et al. Gender difference in delays to diagnosis and health care seeking behaviour in a rural area of Nepal. Int J Tuberc Lung Dis 2001;5(1):24-31.

[5] Paynter S, Hayward A, Wilkinson P, et al. Patient and health service delays in initiating treatment for patients with pulmonary tuberculosis: retrospective cohort study. Int J Tuberc Lung Dis 2004;8(2):180-5.

[6] Gopi PG, Chandrashekharan V, Subramani PR, et al. Failure to initiate treatment for tuberculosis patients diagnosed in a community survey and a health facilities under a DOTS programme in a district of South India. Ind J Tuberc 2005;52:153-6. 